ROCZNIKI NAUK SPOŁECZNYCH

Tom 13(49), numer $2-2021$

DOI: https://doi.org/10.18290/rns21492-7

AGNIESZKA ROGOZIŃSKA

\title{
ZAGROŻENIA JAKO GŁÓWNA DETERMINANTA BEZPIECZEŃSTWA MIĘDZYNARODOWEGO
}

\section{WPROWADZENIE}

Istota bezpieczeństwa międzynarodowego wyraża się w działaniach podejmowanych przez podmioty państwa w celu zapobiegania i eliminowania zagrożeń dla ich istnienia, przetrwania i rozwoju (Ciekanowski i in., 2016, s. 16). Bezpieczeństwo międzynarodowe należy postrzegać jako dynamiczny proces zmieniający się w czasie i przestrzeni. Zakres terminu bezpieczeństwo międzynarodowe w perspektywie ostatnich lat uległ transformacji, a jego współczesne definiowanie jest konsekwencją stale ewoluujących zagrożeń. Wraz ze zmianami zachodzącymi w międzynarodowym środowisku bezpieczeństwa tradycyjny katalog dziedzin bezpieczeństwa o charakterze militarnym i politycznym poszerzył się o nowe, warunkowane rozwojem cywilizacji. Na podstawie analizy literatury przedmiotu za kluczowe dziedziny dla bezpieczeństwa międzynarodowego należy uznać bezpieczeństwo militarne, polityczne, ekonomiczne, informacyjne, w tym w cyberprzestrzeni, społeczne, ekologiczne, kulturowe i zdrowotne, trzeba jednak nadmienić, że katalog ten pozostaje otwarty. Następstwem ewolucji bezpieczeństwa międzynarodowego jest stale zwiększająca się liczba instrumentów oddziaływania i kreowanych przez nie zagrożeń, na ogół o synchronicznym charakterze i różnej amplitudzie rażenia. Zagrożenia dla bezpieczeństwa międzynarodowego charakteryzują się różnorodnością, intensywnością, a także nieprzewidywalnością skali oraz skutków ich wystąpienia. Współczesne bezpieczeństwo ma charakter zintegrowany, kompleksowy, wielowymiarowy, w którym - w zależności od przyjętego kryterium - można wyróżnić różne jego rodzaje, dziedziny, sektory, działy i obszary. Konsekwencją zintegrowania

Dr AgNieSZKa RogOziŃSKA - Uniwersytet Jana Kochanowskiego w Kielcach, Wydział Prawa i Nauk Społecznych, Instytut Nauk o Bezpieczeństwie; adres do korespondencji: ul. Uniwersytecka 15, 25-406 Kielce; e-mail: agnieszka.rogozinska@ujk.edu.pl; ORCID: https://orcid.org/0000-0002-3462-7851. 
sektorów bezpieczeństwa jest zmiana charakteru współczesnych zagrożeń, ewoluujących z jednowymiarowych zagrożeń militarnych lub niemilitarnych w zagrożenia wielowymiarowe.

Tak przedstawiona sytuacja problemowa pozwala na sformułowanie głównego problemu badawczego: Jakie sa teoretyczne aspekty wspótczesnych zagrożeń bezpieczeństwa międzynarodowego? Na sformułowany problem badawczy składają się problemy szczegółowe, sformułowane w postaci pytań: 1) W czym wyraża się istota bezpieczeństwa międzynarodowego? 2) Czym charakteryzuja się zagrożenia dla bezpieczeństwa międzynarodowego?

Celem artykułu jest identyfikacja i ocena definicji bezpieczeństwa międzynarodowego oraz diagnoza współczesnych zagrożeń bezpieczeństwa międzynarodowego. W procesie badawczym wykorzystano metodologię poznania naukowego, w tym głównie analizę i krytykę literatury.

\section{ISTOTA BEZPIECZEŃSTWA MIĘDZYNARODOWEGO}

W literaturze przedmiotu bezpieczeństwo jest definiowane jako teoria i praktyka zapewniania możliwości przetrwania (egzystencji) i realizacji własnych interesów przez podmiot (Koziej, 2011, s. 19). Termin ten jest ujmowany w kontekście wykorzystywania szans (okoliczności sprzyjających), podejmowania wyzwań, redukowania ryzyka oraz przeciwdziałania (zapobieganie i przeciwstawianie się) wszelkiego rodzaju zagrożeniom dla podmiotu i jego interesów ((Mini)Słownik BBN, https://www.bbn.gov.pl/pl/bezpieczenstwonarodowe/minislownik-bbn-propozy/6035, minislownik-bbn-propozycje-no wych-terminow-z-dziedziny-bezpieczenstwa.html). Zgodnie $\mathrm{z}$ etymologią termin „bezpieczeństwo” (łac. securitas, sine cura - beztroski) jest związany z zagrożeniami i uzasadnia słuszność definiowania bezpieczeństwa jako stanu „spokoju, pewności i niezagrożenia” (Świniarski, 1999, s. 13), braku „,zagrożenia fizycznego lub ochronę przed nim" (Gould, Kolb, 1964, s. 629).

Bezpieczeństwo jest procesem, który obejmuje różnorodne środki, w tym działania na arenie wewnętrznej i międzynarodowej, m.in. o charakterze dyplomatycznym, ekonomicznym, militarnym, kulturowym, działania obronne i ochronne. Mają one na celu stworzenie optymalnych warunków bytu i rozwoju narodu i państwa, w tym jego ochrony i obrony jako instytucji politycznej, a także ochronę jednostek i całego społeczeństwa przed zagrożeniami.

Uwzględniając kryterium podmiotowe, wyróżniamy bezpieczeństwo narodowe i międzynarodowe. W zakresie znaczeniowym bezpieczeństwo 
międzynarodowe jest pojęciem szerszym. „Bezpieczeństwo międzynarodowe ma być nie tylko sumą bezpieczeństw narodowych" (Nye, 1989, s. 53), lecz także zawierać w sobie tzw. wzmocnienie zbiorowe, które pozwala na określanie zarówno zewnętrznych aspektów bezpieczeństwa pojedynczych państw, jak i na opisywanie pewności przetrwania i funkcjonowania systemu międzynarodowego.

Powyższe przesłanki pozwalają na uznanie za zasadny poglądu Josepha Nye'a, zgodnie z którym bezpieczeństwo międzynarodowe należy rozpatrywać w kontekście wysiłków podejmowanych w „celu przezwyciężenia wąskiego, etnocentrycznego wymiaru terminu bezpieczeństwo narodowe" (Nye, 1989, s. 53).

Analizowana literatura przedmiotu z zakresu nauk o bezpieczeństwie definiuje bezpieczeństwo międzynarodowe jako proces lub stan środowiska międzynarodowego (regionalnego, kontynentalnego, globalnego) gwarantujący jego stabilność oraz szansę rozwoju uzyskaną poprzez zabezpieczenie przed różnorodnymi zagrożeniami (Pokruszyński, 2012, s. 12). W tym kontekście bezpieczeństwo międzynarodowe dotyczy możliwości przeciwstawienia się negatywnym oddziaływaniom innych podmiotów w międzynarodowym środowisku bezpieczeństwa (Marcinkowski, 2007, s. 59-60), tworząc warunki stabilnego i harmonijnego funkcjonowania i rozwoju oraz zabezpieczając wartości i interesy państwa.

Bezpieczeństwo międzynarodowe zapewniają podmioty (sojusze, organizacje i korporacje trans- i międzynarodowe) działające w wymiarze globalnym. Podmioty te realizują określone funkcje na rzecz pokoju, stabilności oraz rozwoju państw i społeczności międzynarodowej. Ich kooperacja ma na celu podjęcie zbiorowych, zinstytucjonalizowanych wysiłków w celu przeciwstawienia się zagrożeniom dla bezpieczeństwa międzynarodowego. Bezpieczeństwo międzynarodowe w tym kontekście definiują Witold Pokruszyński (Pokruszyński, 2012, s. 12), Ludwik Ehrlich (Ehrlich, 2018, s. 438), Zbigniew Berent (Berent, 1988, s. 115-116). Berent precyzuje ponadto środki służące zabezpieczeniu i rozwojowi bezpieczeństwa międzynarodowego, jako instytucje bezpieczeństwa wojskowego, politycznego, ekonomicznego, kulturalno-cywilizacyjnego, wyznaczając jego obszary (Berent, 1988, s. 115-116). Definicja zaproponowana przez Ryszarda Ziębę określa bezpieczeństwo międzynarodowe jako „zespół warunków, norm i mechanizmów międzynarodowych oraz oddziaływań, które zapewniają każdemu państwu danego systemu międzynarodowego czy regionu mniejszą lub większą pewność niezagrożonego istnienia, przetrwania, stanu posiadania i swobód rozwojowych" (Zięba, 1997, s. 23). Tę definicję należy uznać za najpełniejszą spośród omawianych. Słusznie zauważa Zięba, 
że bezpieczeństwo międzynarodowe odnosi się zarówno do wartości egzystencjalnych państw, jak i większych systemów, wśród których za kluczowe uznaje się stabilność, równowagę, rozwój i współpracę. Wartości te powinny podlegać ochronie państwa poprzez realizację założeń polityki bezpieczeństwa. W celu utrzymania bezpieczeństwa międzynarodowego należy eliminować zagrożenia, których konsekwencje godziłyby w istnienie, przetrwanie, tożsamość oraz rozwój państw i systemów międzynarodowych (s. 23).

Tradycyjne rozumienie bezpieczeństwa, w tym bezpieczeństwa międzynarodowego, sprowadzało się do sposobów przeciwdziałania zagrożeniom militarnym i rozbudowy potencjału wojskowego. W tradycyjnym ujęciu bezpieczeństwo oznaczało wolność od zagrożenia zewnętrznego, osiąganą za pomocą konwencjonalnej obrony. Takie bezpieczeństwo było „państwocentryczne”, państwo było jedynym podmiotem, który zapewniał bezpieczeństwo, oraz jedynym przedmiotem, któremu bezpieczeństwo miało być zapewnione. Współcześnie zagrożenia rzadko przybierają postać zagrożenia dla fizycznego istnienia państwa, jego suwerenności czy integralności terytorialnej. Nowe, pozamilitarne zagrożenia przeniknęły do wszelkich sfer i dziedzin aktywności państwa, przesuwając wymiar bezpieczeństwa militarnego na dalszy plan. Wyodrębnienie poszczególnych kategorii bezpieczeństwa ewaluowało wraz z rozwojem cywilizacyjnym. Przedstawiciel szkoły kopenhaskiej, Barry Buzan, w latach 80. XX wieku postulował, aby badania problemów bezpieczeństwa prowadzić z uwzględnieniem pięciu dziedzin, wyróżniając bezpieczeństwo militarne - związane z układem ofensywnej i obronnej siły zbrojnej państw; bezpieczeństwo polityczne - związane z instytucjonalną stabilnością państw, systemami rządzenia i ideologiami, które zapewniają legitymizację; bezpieczeństwo ekonomiczne - dotyczące dostępu do zasobów, środków finansowych i rynków, konieczne, by zachować oczekiwany poziom dobrobytu i potęgi państwa; bezpieczeństwo społeczne - skoncentrowane na stabilności i rozwoju tradycyjnych wzorców językowych i kulturowych oraz tożsamości i praktykach religijnych i narodowych; ekologiczne - związane z utrzymaniem lokalnego i globalnego wymiaru biosfery jako niezbędnej bazy wszelkiej innej aktywności ludzkiej (Buzan, 1983, s. 4). Obecnie katalog ten należy uznać za niewystarczający. Wraz z ewolucją zagrożeń zachodzącą w międzynarodowym środowisku bezpieczeństwa wachlarz dziedzin bezpieczeństwa rozszerzył się o nowe, warunkowane rozwojem cywilizacji. Włączono do niego bezpieczeństwo informacyjne, którego integralną część stanowi bezpieczeństwo w cyberprzestrzeni, bezpieczeństwo infrastruktury krytycznej, zdrowotne oraz wiele innych. 


\section{CHARAKTERYSTYKA WYBRANYCH ZAGROŻEŃ DLA BEZPIECZEŃSTWA MIĘDZYNARODOWEGO}

Zagrożenia są przeciwieństwem bezpieczeństwa, stanowią o jego przedmiotowym zakresie. Zgodnie z definicją zaproponowaną przez Stanisława Kozieja zagrożenia należy postrzegać jako pośrednie lub bezpośrednie destrukcyjne oddziaływania na podmiot (Koziej, 2011, s. 20). Źródłem zagrożeń dla bezpieczeństwa międzynarodowego są najczęściej państwa realizujące własną politykę zagraniczną, która stoi w sprzeczności z celami innych podmiotów. Sprzeczności te można dostrzec w rywalizacji międzynarodowej (Jemioło, Dawidczyk, 2008, s. 40).

W klasyfikacji zagrożeń wyróżnia się zagrożenia spowodowane bezpośrednią bądź pośrednią działalnością człowieka. Według kryterium sprawstwa dzielą się na zagrożenia militarne i niemilitarne, których wyznacznikiem jest zastosowanie siły jako formy przemocy zbrojnej (Banasik, 2011, s. 196).

Według Stanisława Dworeckiego zagrożenie militarne to podstawowy czynnik godzący bezpośrednio w bezpieczeństwo państwa. Przez zagrożenie militarne bezpieczeństwa państwa rozumie on „splot zdarzeń polityczno-militarnych, w którym, z dużym prawdopodobieństwem, może nastąpić utrata warunków do niezakłóconego bytu i rozwoju państwa lub naruszenie jego suwerenności i integralności terytorialnej" (Dworecki, 1994, s. 25). Należy zgodzić się z Dworeckim, który wśród działań podejmowanych w ramach zagrożeń militarnych wymienia zastosowanie siły zbrojnej i przemocy fizycznej. Niewystarczające obecnie natomiast wydają się proponowane formy zagrożeń: demonstracja siły, dywersja, blokada militarna, szantaż lub prowokacja militarna, incydent graniczny oraz konflikt. Katalog ten powinien uwzględniać chociażby wojny hybrydowe. Bardziej kompleksowy pod tym względem jest podział zaproponowany przez Tadeusza Szczurka, który zagrożenia militarne dzieli na: konflikt zbrojny, użycie lub groźba użycia potencjału militarnego jednego państwa przeciwko drugiemu państwu, inne zagrożenia politycznomilitarne, w tym wojny hybrydowe (Szczurek, 2012, s. 101-103). Jednocześnie wskazuje na bezpośredni sposób ich występowania, poprzez dywersję militarną, prowokację i incydenty graniczne, lub pośredni, do których zalicza szantaż militarny i demonstrację siły. Należy zgodzić się opinią autora, że współczesny konflikt militarny jest typowym zagrożeniem hybrydowym, którym jest równoczesne, zorganizowane, konwencjonalne i niekonwencjonalne militarne lub niemilitarne działanie podjęte przez stronę lub strony 
przeciwne dla osiągnięcia celu politycznego, militarnego, gospodarczego lub innego (tamże).

Uogólniając, należy stwierdzić, że współczesne zagrożenia militarne materializują się w formach militarno-cywilnych działań selektywnie oddziałujących na przeciwne siły zbrojne oraz całe społeczeństwa, często poniżej progu wojny, których celem jest realizacja celów polityki zagranicznej państwa. Przykładem działań o takim charakterze są zagrożenia wynikające $\mathrm{z}$ wojen hybrydowych.

Zagrożenia niemilitarne to „sytuacje niekorzystne lub zespół okoliczności, w których nie występuje czynnik militarny, a z obiektywnej oceny wynika, iż mogą one doprowadzić do stanu (procesu) niebezpiecznego dla określonego podmiotu" (Szczurek, 2012, s. 115). Przedmiotowa typologia zagrożeń niemilitarnych bezpieczeństwa dzieli je na zagrożenia polityczne, ekonomiczne, społeczne, informacyjne, ekologiczne i kulturowe (Jakubczak, 2003, s. 92). Ostatnie dwa lata uświadomiły nam, że do katalogu tego dołączyć należy zagrożenia dla bezpieczeństwa zdrowotnego.

1. Zagrożenia polityczne są rozumiane jako stan lub sytuacje, w których nasilają się działania zorganizowanych grup społecznych i politycznych, uniemożliwiające wypełnianie przez państwo jego głównych funkcji, a przez to osłabienie lub uniemożliwienie działania organów lub instytucji państwa realizujących cele i interesy narodowe (Łepkowski, 2013, s. 167). Literatura przedmiotu określa ten rodzaj zagrożeń ,jako stan, w którym nasilają się zadania zorganizowanych grup społecznych (politycznych) uniemożliwiających wypełnianie przez państwo jego głównych funkcji, a przez to osłabiające lub niweczące działania organów lub instytucji realizujących cele i interesy narodowe" (Kaczmarek i in., 2008, s. 153). W ocenie Lecha Chojnowskiego zagrożenia polityczne systemu międzynarodowego mogą stanowić konsekwencje zamierzonych działań uczestników stosunków międzynarodowych wynikających z: aktywności mocarstw zmierzających do powiększania swoich stref wpływów; kwestionowania istniejącego układu granic państwowych i dążenia do ich rewizji, z pogwałceniem obowiązujących w tym zakresie regulacji międzynarodowych; nieprzestrzegania uzgodnionych i ustanowionych instytucji i reżimów międzynarodowych, w szczególności prawa międzynarodowego; braku gotowości do współpracy międzynarodowej mającej na celu stabilizowanie ładu systemu międzynarodowego poprzez zapobieganie i pokojowe rozwiązywanie sporów i konfliktów międzynarodowych; nieprzestrzegania zasad pokojowego współistnienia polegających na wzajemnym poszanowaniu integralności terytorialnej i suwerenności, wzajemnej nieagresji, 
wzajemnej nieinterwencji w sprawy wewnętrzne, równości i wzajemnej korzyści; rozwijania lub wspierania terroryzmu międzynarodowego z wykorzystaniem zróżnicowania kulturowego i stymulowanie fundamentalizmu, zwłaszcza religijnego; podsycania i rozwijania agresywnych ideologii i ruchów politycznych, odwołujących się do agresywnego nacjonalizmu, rasizmu, ksenofobii, szowinizmu i innych form nietolerancji, które prowadzą do głębokich podziałów ideologiczno-politycznych; wykorzystywania różnic polityczno-ideologicznych stanowiących podstawy ustrojowe państw, które same w sobie mogą generować sytuacje konfliktowe (Kaczmarek i in., 2008, s. 153).

Sławomir Zalewski ten rodzaj zagrożenia odnosi do bezpieczeństwa politycznego państwa. Są nimi hipotetyczne lub realne sytuacje, w których szeroko płaszczyznowo lub fragmentarycznie zakłócają one działalność systemu politycznego państwa, obniżając jakość realizowanych przez niego funkcji, a w skrajnych przypadkach prowadząc do ograniczenia lub utraty jego legitymizacji (Zalewski, 2010, s. 205). Za najważniejsze z nich uznał: patologie procesu decyzyjnego rządu, wzrost znaczenia powiązań nieformalnych w decyzjach podejmowanych w sferze administrowania sprawami publicznymi, korupcję władzy publicznej, przestępczość gospodarczą i zagrożenia asymetryczne (terroryzm polityczny) (s. 206). Ponadto zagrożenia te w wymiarze zewnętrznym państwa obejmują: działania służb specjalnych i obcego wywiadu, decyzje: innych państw, organizacji, instytucji międzynarodowych lub podmiotów niemających statusu prawnego państwa. Do zagrożeń politycznych zaliczamy: wspieranie opozycji, spory na tle etnicznym, ideologicznym lub religijnym, tworzenie strefy wpływów, regionalnej lub lokalnej dominacji, korupcję struktur władzy i aparatu administracji, akty terrorystyczne przeciwko instytucji państwa, organizacji międzynarodowej, koalicji lub sojuszowi militarnemu.

2. Zagrożenia ekonomiczne (gospodarcze) są rozumiane jako stan lub sytuacja, w której państwo nie może przeciwstawić się oddziaływaniom zewnętrznym i wewnętrznym, które uniemożliwią jego rozwój ekonomiczny zgodnie z przyjętymi założeniami, kierunkami oraz tempem. Przez to osłabiają one państwowy potencjał gospodarczo-obronny oraz zdolność do skutecznego przeciwstawienia się zewnętrznym naciskom, które mogą doprowadzić do zaburzeń rozwoju. Zagrożenia ekonomiczne dla bezpieczeństwa międzynarodowego są utożsamiane ze stanem, w którym „państwo nie może przeciwstawić się takim oddziaływaniom zewnętrznym i wewnętrznym, które uniemożliwiają rozwój ekonomiczny zgodny z określonymi kierunkami i tempem, a przez to osłabiają potencjał gospodarczo-obronny" (Stankiewicz, 1986, s. 29). Są skoncentrowane na dostępie do zasobów, środków finansowych i rynków, poziomie dobrobytu i potęgi państwa-oponenta. 
Zgodne z propozycją Krzysztofa Księżopolskiego bezpieczeństwo ekonomiczne odnosi się do zagrożeń mających wpływ na gospodarkę narodową ogólnie i uwzględnia elementy synergii zagrożeń różnych typów i ich wpływu na bezpieczeństwo ekonomiczne (np. zagrożenia militarne czy społeczno-polityczne znajdują przełożenie na sferę ekonomiczną) (Księżopolski, 2011, s. 68). W kontekście zagrożeń bezpieczeństwo ekonomiczne definiuje się jako możliwość współpracy na rzecz przeciwdziałania zagrożeniom i budowy bezpieczeństwa ekonomicznego (np. sojusze wojskowe, współpraca międzynarodowa wynikająca z użytkowania infrastruktury krytycznej czy sojusze gospodarcze itp.) (Ciszek, 2013, s. 57-58).

Ciekawy z punktu widzenia identyfikacji zagrożeń bezpieczeństwa ekonomicznego jest katalog zagrożeń wymienionych przez Mariusza Ciszka. Wskazuje on, że źródłem zagrożeń bezpieczeństwa ekonomicznego mogą być: niekorzystne proporcje $\mathrm{w}$ tworzeniu i podziale produktu krajowego brutto (PKB, błędne kierunki polityki finansowej i gospodarczej kraju, zasoby i struktura bogactw naturalnych kraju, infrastruktura produkcyjna, infrastruktura transportowa i łączność, zasoby ludzkie) (Ciszek, 2013, s. 47-58).

Stanisław Lipiński wymienia następujące zagrożenia ekonomiczne: zadłużenie państwa, wysoką inflację lub deflację, nadmierny import, brak nowych technologii i niską innowacyjność, restrykcje gospodarcze, izolację ekonomiczną państwa, limity produkcji, utratę rynków zbytu, złą konkurencję, utratę majątku narodowego i potencjału produkcyjnego, ucieczkę kapitału obcego i inwestorów zagranicznych, brak infrastruktury transportowej i komunikacyjnej, niewydolność produkcyjną i finansową gospodarki narodowej (Lipiński, 2008, s. 68).

Księżopolski dzieli zbiór zagrożeń bezpieczeństwa na cztery podzbiory: zagrożenia finansowe, zagrożenia surowcowo-energetyczne, zagrożenia żywnościowe oraz zagrożenia wynikające z dostępu do czystej wody. Tak zaprezentowane podzbiory zagrożeń bezpieczeństwa ekonomicznego pozwalają na szerokie możliwości dopasowania zagrożeń będących wynikiem decyzji politycznych i funkcjonowania aktorów finansowych oraz problemów wynikających z dostępności surowców energetycznych (Księżopolski, 2008, s. 68).

Na potrzeby artykułu oraz związanej z nim analizy zagrożeń bezpieczeństwa najbardziej prawidłowa wydaje się definicja zaproponowana przez Tomasza Szubrychta. Oprócz przytoczonej istoty funkcjonowania bezpieczeństwa ekonomicznego (harmonijny rozwój gospodarki oraz zapewnienie odpowiedniego poziomu życia obywateli) autor wymienia elementy, które mogą wpływać na poziom bezpieczeństwa ekonomicznego (,niezakłócony dostęp do 
surowców, rynków zbytu, kapitału, nowoczesnych technologii czy informacji”) (Szubrycht, 2006, s. 91-93).

3. Zagrożenia dla bezpieczeństwa społecznego w międzynarodowym środowisku bezpieczeństwa dotyczą całokształtu działań prawnych i organizacyjnych realizowanych przez podmioty rządowe, krajowe i międzynarodowe, pozarządowe i samych obywateli. Na podstawie katalogu współczesnych wyzwań i zagrożeń wskazuje się na podstawowe potrzeby społeczeństwa w dziedzinie bezpieczeństwa. Zgodnie ze stanowiskiem Waldemara Kitlera można wyodrębnić dwa zasadnicze obszary bezpieczeństwa: pierwszy obszar odnosi się do zapewnienia społeczeństwu potrzeby bytu i rozwoju, jednocześnie społeczeństwo dostrzega iż, państwo może być narażone na różnorodne zagrożenia, sytuacje kryzysowe, spowodowane czynnikami politycznymi, społecznymi, kulturowymi itd., drugi - dotyczy zapewnienia stabilnego poziomu życia jednostkom, rodzinom i grupom społecznym oraz niedopuszczenia do ich marginalizacji i wykluczenia społecznego (Kitler, 2011, 34). Wiążą się one z prawdopodobieństwem wystąpienia niepożądanych zjawisk społecznych oraz ograniczeniem ryzyka związanego z przetrwaniem i jakością życia w sferze ekonomicznej i kulturowej. Zagrożenia dla bezpieczeństwa społecznego są postrzegane przede wszystkim w wymiarze egzystencjalnym, ,jako ochrona podstaw życia ludzi, zaspokajanie ich potrzeb oraz umożliwianie realizacji aspiracji życiowych" (Gierszewski, 2018, s. 25). Zagrożenia społeczne odnoszą się do niebezpieczeństwa utraty życia i zdrowia, tożsamości narodowej i etnicznej poszczególnych społeczności, a także bezpieczeństwa socjalnego i publicznego. Zaliczamy do nich: naruszenie praw człowieka i podstawowych wolności; uprzedzenia kulturowe i religijne oraz dyskryminację mniejszości narodowych, etnicznych, kulturowych, religijnych i językowych; dyskryminację płci; manipulacje świadomością i psychiką za pomocą środków masowego przekazu, ograniczanie wolności mediów; nacjonalizm, szowinizm, ksenofobię, fundamentalizm religijny; patologie społeczne (przestępczość, terror, struktury mafijne, narkomanię, epidemie, prostytucję, alkoholizm, analfabetyzm, masowe bezrobocie, rodziny dysfunkcjonalne); masowe migracje (ekonomiczne, ekologiczne); alienację społeczną; nadużycia wiedzy przeciwko ludzkości; dewaluację wartości ludzkich, zacieranie różnic między dobrem a złem; kult przemocy, brutalizację stosunków międzyludzkich; katastrofy i kataklizmy prowadzące do naruszenia systemu społecznego; upadek systemu ochrony zdrowia ludności; kradzieże dóbr kultury; kryzysy demograficzne; ubożenie i głód dużych grup społecznych; 
degradację infrastruktury komunikacyjnej, mieszkaniowej i środków transportu (Jakubczak, 2003, s. 94-95).

4. Istotą zagrożeń informacyjnych dla bezpieczeństwa międzynarodowego jest oddziaływanie na świadomość masową w cyberprzestrzeni oraz przestrzeni komunikacyjnej poprzez zastosowanie szerokiego wachlarza instrumentów oddziaływania, wśród których najważniejsze miejsce zajmują propaganda, manipulacja i dezinformacja. Są one rozumiane jako działania destrukcyjne prowadzone przez świadomych lub nieświadomych użytkowników systemów i sieci komputerowych na skutek działania zewnętrznego lub wewnętrznego czynnika, są celowo lub przypadkowo niszczone lub uszkodzone, zwłaszcza elementy miękkie i twarde infrastruktury informatycznej, powodując dysfunkcję pozostałych odbiorców tego systemu. Do zagrożeń bezpieczeństwa informacyjnego zaliczamy: szpiegostwo, zagrożenia cybernetyczne, szantaż, wojnę informacyjną, działania aktywistów i grup hakerskich (Bączek, 2005, s. 85). W obrębie zagrożeń informacyjnych identyfikujemy zagrożenia bezpieczeństwa w cyberprzestrzeni. W opinii ekspertów Biura Bezpieczeństwa Narodowego (Doktryna cyberbezpieczeństwa Rzeczypospolitej Polskiej, 2015) za najgroźniejsze zagrożenia cybernetyczne związane z cyberterroryzmem i walką informacyjną uważa się działania w cyberprzestrzeni obejmujące aktywizm, hakiwizm i koordynację przez Internet działań grup terrorystycznych, organizacji kierowanych przez państwa lub ugrupowania religijne. Zagrożenia cybernetyczne przyjmują wymiar działalności zewnętrznej i wewnętrznej, wykorzystując cyberszpiegostwo, działanie służb specjalnych i terrorystycznych prowadzące do kryzysów i konfliktów w sferze wirtualnej i realnej. Mogą polegać na atakach za pomocą wirusów, robaków, trojanów w sieci na infrastrukturę krytyczną państwa oraz system obronny państwa, a także na dezinformacji, propagandzie i manipulacji, cyberprzestępczości, skrytych działaniach dyplomacji mających na celu obniżenie pozycji międzynarodowej i prestiżu danego państwa. Do zagrożeń cybernetycznych możemy zaliczyć: „,wirtualne blokady (zablokowanie witryny w sieci); ataki mailowe (nadmierna liczba maili, w krótkim okresie); bezprawne włamanie się do komputerów, serwerów, baz danych; atak przy pomocy wirusów, robaków, trojanów w sieci i w efekcie zakłócenie w państwie pracy systemów teleinformatycznych kierowania i wykonawczych - operacyjnych, infrastruktury krytycznej państwa, takich jak: finansów, zarządzania bezpieczeństwem, kierowania transportem i komunikacją, informatycznych" (tamże).

5. Zagrożenia ekologiczne bezpieczeństwa odnoszą się do funkcjonowania żywej przyrody oraz warunków życia człowieka w środowisku naturalnym, 
a także trwałego rozwoju narodu. Zagrożenia te może wywołać działalność człowieka (zagrożenia antropomorficzne) i czynniki naturalne (zagrożenia nieantropomorficzne). Definiowane są jako rodzaj zagrożenia, w wyniku którego może nastąpić niebezpieczeństwo dla istot żywych na skutek zmian w środowisku naturalnym. Do tego typu zagrożeń możemy zaliczyć: niekontrolowaną eksploatację zasobów naturalnych (wyrąb lasów, nadmierne odłowy zwierząt, rabunkowe wydobywanie kopalin); masowe zanieczyszczanie wody, powietrza, gleby; brak gospodarki odpadami komunalnymi, przemysłowymi i nuklearnymi; stosowanie niebezpiecznych technologii przemysłowych prowadzących do zmian w atmosferze (likwidacja powłoki ozonowej, ocieplanie klimatu, wzrost emisji promieniowania ultrafioletowego); katastrofy naturalne i przemysłowe; naruszenie stosunków wodnych w środowisku (odwracanie biegu rzek, brak racjonalnej gospodarki leśnej) prowadzące do erozji gleb, osuwisk i pustynnienia terenów; chaotyczną urbanizację; próby nuklearne i nowych typów broni (np. geofizyczna, meteorologiczna) (Jakubczak, Flis, 2006, s. 113).

Sfera środowiska naturalnego jest zagrożona $w$ trzech typach relacji: „zagrożeń dla ludności ze strony środowiska poprzez katastrofy naturalne, ocieplenie klimatu, epidemie i pandemie; zagrożeń dla środowiska spowodowanych działalnością człowieka: wyrąb lasów, emisja dwutlenku węgla lub freonu, zanieczyszczenia wód i gleb; zagrożeń dla środowiska naturalnego powodujących stopniową jego degradację i wpływających pośrednio na życie społeczne i przyrodnicze" (Wrzosek, 2010, s. 49).

6. Zagrożenia dla bezpieczeństwa kulturowego można zidentyfikować w sferze materialnej i niematerialnej. Zagrożenia materialne dotyczą ochrony wytworów kultury i dziedzictwa narodowego. Sfera niematerialna jest identyfikowana $z$ naruszeniem praw grup etnicznych, prawa do kultury i innych gwarantowanych międzynarodowo praw. Podkreślają one ścisłe związki między bezpieczeństwem kulturowym a prawami i wolnościami człowieka (Czaja, 2004, s. 9-10). Wśród kluczowych zagrożeń dla bezpieczeństwa narodowego należy wymienić: pogłębiający się kryzys tożsamości narodowej, spadek poczucia więzi kulturowej; ograniczenie suwerenności państwa; internacjonalizacja zagrożeń społecznych; wzrost zależności kulturowej; spadek środków na kulturę i politykę kulturalną, kryzys państwa narodowego i jego przenoszenie na kulturę; uniformizacja treści przekazywanych przez media; wzrost ekspansji kultury masowej; wzrost dezorientacji i kryzys wartości związanych z ekspansją kultury masowej; przyspieszenie procesu rozkładu tradycyjnych więzi międzyludzkich (tamże, s. 150). 
Zgodnie ze stwierdzeniem Andrzeja Dawidczyka (Dawidczyk, 2001, s. 16) bezpieczeństwo kulturowe wiąże się z koniecznością zapewnienia ochrony tożsamości narodowej i przeciwdziałania zagrożeniom dla kultury, religii i języka w związku z napływem obcych wartości z innych kręgów kulturowych. Odnosi się ono do materialnych i duchowych wartości kultury i religii, które są kluczowe dla egzystencji jednostki, rodziny i narodu. W tym kontekście globalizacja jest podstawowym zagrożeniem rodzimej kultury poprzez wymianę i napływ wartości, symboli oraz zwyczajów panujących w różnych kręgach cywilizacyjnych.

7. Zagrożenia dla bezpieczeństwa zdrowotnego należy rozumieć jako „choroby [...], w tym cywilizacyjne, oraz inne zagrożenia zdrowotne, środowiskowe i społeczne, których efektem jest utrata zdrowia i życia człowieka lub zbiorowości społecznej państwa" (Chorąży, Kostowski, 2010, s. 47-52). Do katalogu zagrożeń zdrowotnych bezpośrednich możemy zaliczyć możemy: choroby cywilizacyjne, klimatyczno-przyrodnicze, zagrożenia komunikacyjne, choroby społeczne (alkoholizm, narkomania, choroby psychiczne), epidemie i pandemie, złe warunki pracy, zaś za zagrożenia pośrednie uznaje się niskie finansowanie: służby zdrowia, infrastruktury komunikacyjnej, bezpieczeństwa i higieny pracy, przeciwdziałania skutkom zagrożeń klimatycznych, profilaktyki zwalczania chorób cywilizacyjnych oraz rozwoju ratownictwa medycznego (Ameljańczyk, Ameljańczyk, b.r.).

Podsumowując można z dużym prawdopodobieństwem stwierdzić, że wymieniona powyżej lista zagrożeń nie jest zamknięta i stale ewoluuje. Zagrożenia cechuje znaczący wpływ na bezpieczeństwo w skali międzynarodowej, ale ich konsekwencje oddziałują również na wiele pojedynczych państw. Dlatego ważne wydaje się rozpatrywanie aspektów bezpieczeństwa współczesnych państw z uwzględnieniem trendów i czynników występujących w różnych, do tej pory wydawałoby się niepowiązanych ze sobą obszarach, takich jak polityka, ekonomia, społeczeństwo, kultura, informacja, infrastruktura krytyczna i inne. Zmiany zachodzące w poszczególnych obszarach wpływają na siebie, niejednokrotnie zwiększając ryzyko wystąpienia zagrożeń istotnych nie tylko w skali globalnej, lecz także najbardziej odczuwalnych w skali regionalnej i lokalnej 


\section{WNIOSKI}

Podsumowując zamieszczone $\mathrm{w}$ artykule treści i odnosząc się do postawionego problemu badawczego należy stwierdzić, że bezpieczeństwo międzynarodowe zawsze jest związane $\mathrm{z}$ zagrożeniami. Istota bezpieczeństwa międzynarodowego wyraża się $\mathrm{w}$ działaniach podejmowanych przez podmioty bezpieczeństwa w celu zapobiegania i eliminowania zagrożeń dla ich istnienia, przetrwania i rozwoju (Ciekanowski i in., 2016, s. 20). Zakres terminu „bezpieczeństwo międzynarodowe" uległ transformacji, a jego współczesne definiowanie jest konsekwencją stale ewoluujących zagrożeń. Dokonane porównanie definicji bezpieczeństwa międzynarodowego pozwala na wyodrębnienie ich cech wspólnych, które pozwalają określić bezpieczeństwo międzynarodowe jako całokształt więzi występujących między poszczególnymi uczestnikami stosunków międzynarodowych i instytucjami o charakterze globalnym, które są w stanie współpracować na podstawie obowiązujących zasad prawa międzynarodowego w celu utrzymania pokoju poprzez wyeliminowanie różnorodnych zagrożeń.

Zagrożenia bezpieczeństwa międzynarodowego to zbiór destrukcyjnych zjawisk, czynników, procesów i zdarzeń podmiotów społecznych oraz elementów środowiska przyrodniczego, które godzą bezpośrednio w ochraniane przez społeczeństwa i społeczność międzynarodową priorytetowe wartości. Problematyka zagrożeń bezpieczeństwa międzynarodowego łączy się z ryzykiem utarty wartości chronionych i podejmowanych działań zapobiegawczych oraz obronnych. Sposób postępowania wobec zagrożeń bezpieczeństwa odgrywa główną rolę w rozwiązywaniu problemów bezpieczeństwa. Na podstawie analizy literatury przedmiotu za kluczowe dziedziny dla bezpieczeństwa międzynarodowego należy uznać bezpieczeństwo militarne, polityczne, ekonomiczne, informacyjne, w tym w cyberprzestrzeni, społeczne, ekologiczne kulturowe i zdrowotne.

Katalog zagrożeń dla bezpieczeństwa międzynarodowego i ich typologii nieustannie się powiększa. Zagrożenia dla bezpieczeństwa międzynarodowego są implementowane pakietowo, poprzez zsynchronizowane użycie poszczególnych instrumentów oddziaływania. Oprócz militarnych zagrożeń bezpieczeństwa międzynarodowego współcześnie identyfikujemy również zagrożenia o charakterze niemilitarnym, których znaczenie i wpływ są znacznie większe niż w przeszłości. Fakt ten jest warunkowany ich liczbą, częstotliwością występowania oraz zasięgiem oddziaływania (Banasik, 2019, s. 28-29). 


\section{BIBLIOGRAFIA}

Ameljańczyk A., Ameljańczyk T. (b.r.), System monitorowania bezpieczeństwa zdrowotnego w państwie i jego zagrożeń, http://roczniki_kae.sgh.waw.pl/roczniki_kae_z_25_01.pdf.

Banasik M. (2011), Kierunki zmian w zarzadzaniu kryzysowym resortu obrony narodowej, [w:] G. Sobolewski, D. Majchrzak (red.), Zarzadzanie kryzysowe w systemie bezpieczeństwa narodowego, Warszawa: Akademia Obrony Narodowej, s. 190-205.

Banasik M. (2019), Zagrożenia Federacji Rosyjskiej i euroatlantycka perspektywa bezpieczeństwa, Warszawa: Difin.

Bączek P. (2005), Zagrożenia informacyjne a bezpieczeństwo państwa polskiego, Toruń: Wydawnictwo Adam Marszałek.

Berent Z. (1988), Pokój międzynarodowy i bezpieczeństwo - próba definicji, Sprawy Międzynarodowe $\mathrm{nr}$ 6, s. 111-122.

Buzan B. (1983), People, states \& fear: The national security problem in international relations. London: Wheatsheaf Books.

Chojnowski L. (2012), Polityczny sektor bezpieczeństwa, Zeszyty Naukowe WSOWL nr 3, s. 108-120.

Chorąży M., Kostowski W. (2010), Wybrane zagrożenia zdrowotne, Nauka nr 4, s. 47-52.

Ciekanowski Z., Nowicka J., Wyrębek H. (2016), Bezpieczeństwo państwa w obliczu wspótczesnych zagrożeń, Siedlce: Uniwersytet Przyrodniczo-Humanistyczny w Siedlcach.

Ciszek M. (2013), Filozofia ujmowania zagrożeń ekonomicznych dla bezpieczeństwa narodowego RP i stabilności wewnętrznej państwa, Doctrina. Studia społeczno-polityczne nr 10(10), 47-58.

Czaja J. (2004), Bezpieczeństwo kulturowe. Aspekty pojęciowe, Państwo i Społeczeństwo nr 4(3), s. 5-23.

Dawidczyk A. (2001), Nowe wyzwania, zagrożenia i szanse dla bezpieczeństwa Polski u progu XXI wieku, Warszawa: Akademia Obrony Narodowej.

Doktryna cyberbezpieczeństwa Rzeczypospolitej (2015), 22 stycznia, http://www.bbn.gov.pl/ $\mathrm{ftp} / \mathrm{dok} / 01 / \mathrm{DCB} \cdot \mathrm{pdf}$

Dworecki S. (1994), Zagrożenia bezpieczeństwa państwa, Warszawa: Akademia Obrony Narodowej.

Ehrlich L. (2018), Wstęp do nauki o stosunkach międzynarodowych, Kraków: Znak.

Gierszewski J. (2018), Bezpieczeństwo społeczne jako dziedzina bezpieczeństwa narodowego, Historia i Polityka nr 23(30), s. 21-38.

Glen A. (2011), Zagrożenia bezpieczeństwa narodowego Rzeczypospolitej Polskiej, [w:] Z.A. Piątek (red.), Edukacja na rzecz bezpieczeństwa. Wybrane problemy, Warszawa: CSIEE.

Gould J.W., Kolb W.L. (1964), A dictionnary of the social science, London: The Free Press.

Grzywacz W. (1984), Infrastruktura transportu, Warszawa: WKiŁ.

Jakubczak R. (2003), Obrona narodowa w tworzeniu bezpieczeństwa III RP, Warszawa: Bellona.

Jakubczak R., Flis J. (2006), Bezpieczeństwo narodowe Polski XXI wieku, Warszawa: Akademia Obrony Narodowej.

Jemioło T., Dawidczyk A. (2008), Wprowadzenie do metodologii badań bezpieczeństwa, Warszawa: Akademia Obrony Narodowej.

Kaczmarek J., Łepkowski W., Zdrodowski B. (red.) (2008), Słownik terminów z zakresu bezpieczeństwa narodowego, Warszawa: Akademia Obrony Narodowej.

Karst Z. (1986), Techniczno-ekonomiczna infrastruktura gospodarki narodowej, Warszawa: PWN. 
Kitler W. (2011), Bezpieczeństwo narodowe RP: podstawowe kategorie, uwarunkowania, system, Warszawa: Akademia Obrony Narodowej.

Koziej S. (2011), Bezpieczeństwo: istota, podstawowe kategorie $i$ historyczna ewolucja, Bezpieczeństwo Narodowe nr 18(2), s. 19-39, https://www.bbn.gov.pl/download/1/7803/ Bezpieczenstwoistotapodstawowekategorieihistorycznaewolucja.pdf

Księżopolski K.M. (2011), Bezpieczeństwo ekonomiczne, Warszawa: Elipsa.

Lidwa W., Krzeszowski W., Więcek W., Kamiński P. (2012), Ochrona infrastruktury krytycznej, Warszawa: Akademia Obrony Narodowej.

Lipiński S. (2008), Zagrożenia naturalne i cywilizacyjne, Warszawa: WSBiOŚ.

Łepkowski W. (2013), Stownik terminów z zakresu bezpieczeństwa narodowego, Warszawa: Akademia Obrony Narodowej.

Marcinkowski C. (2007), Wspótczesne środowisko bezpieczeństwa międzynarodowego, Zeszyty Naukowe AON nr 2, s. 57-67.

(Mini)stownik BBN: Propozycje nowych terminów z dziedziny bezpieczeństwa, https://www.bbn. gov.pl/pl/bezpieczenstwo-narodowe/minislownik-bbn-propozy/6035,MINISLOWNIK-BBN-Pro pozycje-nowych-terminow-z-dziedziny-bezpieczenstwa.html

Nye S., Jr. (1989), Problemy badań nad bezpieczeństwem, Sprawy Międzynarodowe nr 6, s. 51-64.

Pietraś M. (1996), Bezpieczeństwo ekologiczne w Europie, Lublin: UMCS.

Pokruszyński W. (2012), Bezpieczeństwo. Teoria i praktyka, Józefów: WSGE.

Sójka W. (2016), Zagrożenia bezpieczeństwa narodowego RP w XXI wieku - wspótczesna pojęcia, zakres, źródta, kwalifikacje, Warszawa: Akademia Obrony Narodowej.

Stankiewicz W. (1986), Zagadnienia bezpieczeństwa ekonomicznego a gospodarka obronna, [w:] Z. Kołodziejak (red.), Bezpieczeństwo ekonomiczne. Teoria i praktyka, Łódź: Uniwersytet Łódzki, s. 10-33.

Szczurek T. (2012), Od deskrypcji do antycypacji wykorzystania potencjału militarnego $w$ ksztattowaniu bezpieczeństwa nowoczesnych wspólnot państwowych wobec rozwoju zagrożeń niemilitarnych, Warszawa: WAT.

Szubrycht T. (2006), Wspótczesne aspekty bezpieczeństwa państwa, Zeszyty Naukowe Akademii Marynarki Wojennej nr 4 (167), s. 87-98.

Świniarski J. (1999), Filozoficzne podstawy edukacji dla bezpieczeństwa, Warszawa: MON.

Ustawa z dnia 26 kwietnia 2007 roku o zarzadzaniu kryzysowym (Dz. U. z 2007 r., nr 89, poz. 590 z późn. zmianami).

Wrzosek M. (2010), Identyfikacja zagrożeń organizacji zhierarchizowanej, Warszawa: AON.

Zalewski S. (2010), Bezpieczeństwo polityczne państwa: studium funkcjonalności instytucji, Siedlce: Akademia Podlaska.

Zięba R. (1997), Kategoria bezpieczeństwa w nauce o stosunkach międzynarodowych, [w:] D.B. Bobrov, E. Haliżak (red.), Bezpieczeństwo narodowe i międzynarodowe u schytku XX wieku, Warszawa: Uniwersytet Warszawski, s. 3-25. 


\title{
ZAGROŻENIA JAKO GŁÓWNA DETERMINANTA BEZPIECZEŃSTWA MIĘDZYNARODOWEGO
}

\author{
Streszczenie
}

Istota bezpieczeństwa międzynarodowego tkwi w możliwości przeciwstawienia się zagrożeniom kreowanym dla podmiotu poprzez tworzenie warunków jego stabilnego i harmonijnego funkcjonowania i rozwoju oraz zabezpieczenia wartości i interesów państwa. Celem artykułu jest identyfikacja i ocena definicji bezpieczeństwa międzynarodowego, a także diagnoza współczesnych zagrożeń bezpieczeństwa międzynarodowego. Główny problem badawczy sformułowano w postaci pytania: Jakie są teoretyczne aspekty współczesnych zagrożeń bezpieczeństwa międzynarodowego? W procesie badawczym wykorzystano metodologię pozna-nia naukowego, w tym głównie analizę i krytykę literatury.

Słowa kluczowe: bezpieczeństwo; bezpieczeństwo międzynarodowe; zagrożenia; teoria.

\section{THREATS AS THE MAIN DETERMINANT OF INTERNATIONAL SECURITY}

\section{Summary}

The essence of international security concerns the possibility of counteracting threats created by other entities, creating conditions for its stable and harmonious functioning and development, and securing the values and interests of the state. The aim of the article is to identify the definition of international security and to diagnose contemporary threats to international security. The main research problem was formulated in the form of the question: What are the theoretical aspects of contemporary threats to international security? In the research process, the methodology of scientific cognition was used, including mainly the analysis and criticism of literature.

Keywords: security; international security; threats; theory. 